\title{
Liturgiczna eklezjologia sakramentu kapłaństwa w obrządku wschodnim
}

Sakramenty święceń biskupa, prezbitera i diakona Bogusław Nadolski słusznie nazywa w swoim podręczniku „sakramentami służby wspólnocie kościelnej" ${ }^{1}$. Posługi święceń są więc ustanowione dla wspólnoty Kościoła. Współczesna liturgika zachodnia stwierdza jednak, że posługi te nie są delegowane przez wspólnotę ani stwarzane przez wspólnotę, ale powstają razem ze wspólnotą dzięki działaniu Ducha Świętego, a swój fundament posiadają w Chrystusie².

Teologia prawosławna zgadza się, że to sam Bóg przeznacza i wybiera osoby do służby w Kościele, ale podkreśla, że Duch tchnie w Kościele i w Kościele udzielane są Jego dary, gdzie realizują się różne posługi. Dlatego Nikołaj Afanasjew (profesor Instytutu Teologii Prawosławnej św. Sergiusza w Paryżu), rozwijając temat eklezjologii kapłaństwa, pisze, że wszystkie osoby wypełniające posługi w Kościele powinny zostać w nie wprowadzone przez Kościół’ ${ }^{3}$ Ustanowienie kogoś pełniącym daną posługę nie jest zwykłym naznaczeniem ani określeniem, ale aktem łaski, w którym Bóg zsyła dary Ducha dla służby w Kościele. Ostatecznie więc to Bóg ustanawia poszczególne służby, ale ustanawia je w Kościele i dla Kościoła, dlatego Kościół uczestniczy w tych ustanowieniach.

Wydaje się, że wschodnia teologia kapłaństwa, zbliżona wprawdzie do myśli zachodniej, mocniej podkreśla fakt udziału wspólnoty Kościoła w udzielaniu sakramentu święceń poprzez delegowanie (stwarzanie) kandydatów do ich przyjęcia. Na takie wnioski pozwala tym teologom

\footnotetext{
${ }^{1}$ B. Nadolski, Liturgika, t. 3, Poznań 1992, s. 155.

${ }^{2}$ Zob. Y. Congar, Ministères et structuration de l'Église, „La Maison-Dieu” 102 (1970), s. 13.

${ }^{3}$ Zob. N. Afanasjew, Eklezjologija wstuplenija w klir, Kiev 1997, s. 8-9.
} 
liturgia sakramentu święceń w obrządku wschodnim, która posiada wiele elementów tradycji wczesnego chrześcijaństwa, gdy wpływ wiernych na wybór biskupów i prezbiterów był znacznie większy niż to jest dzisiaj w obydwu zresztą Kościołach. Mimo upływu czasu wschodnia liturgia święceń (w obrządku bizantyjskim) zachowała dosyć prosty i jasny przebieg w odróżnieniu od liturgii zachodniej (zwłaszcza w jej wersji sprzed reformy soborowej) ${ }^{4}$. W niniejszym artykule postaramy się więc pokazać rolę i miejsce Kościoła jako wspólnoty w obrzędach sakramentu kapłaństwa w obrządku bizantyjskim. Odpowiedź na pytanie, jak Kościół uczestniczy w obrzędach święceń, pozwala równocześnie na przybliżenie zasadniczych myśli wschodniej eklezjologii obejmującej temat sakramentu kapłaństwa i szerzej - liturgicznej służby we wspólnocie Kościoła.

$\mathrm{Na}$ początku trzeba wyjaśnić terminologię związaną w Kościele wschodnim z określeniem wyższych i niższych święceń - odpowiednio

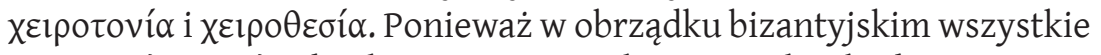
stopnie święceń udzielane są przez włożenie rąk, obydwa terminy

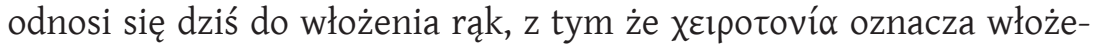

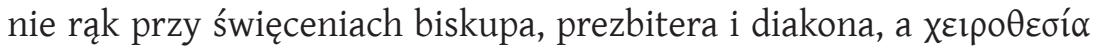
włożenie rąk przy ustanowieniu serii posług. Oryginalne, historyczne znaczenie tych pojęć różni się od współczesnego zastosowania.

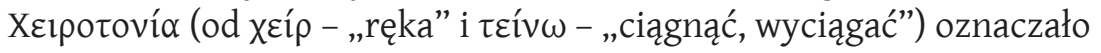
głosowanie przez podniesienie ręki na zebraniach ludu, a więc także akt wyboru ${ }^{5}$. Pierwszym elementem starożytnej liturgii sakramentu

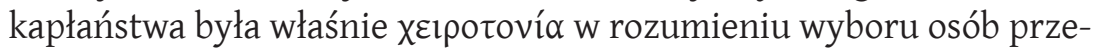
znaczonych do danej posługi. Ten wybór zakładał ustanowienie danej osoby do konkretnej posługi, które dokonywało się przez szereg nastę-

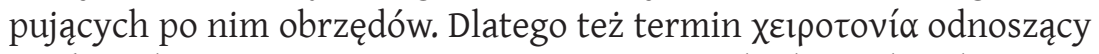
się do wyboru w szerszym rozumieniu oznaczał także cały sakrament święceń. Nikołaj Afanasjew wskazuje na takie użycie tego terminu w Dz 14, 23 (ustanowienie starszych), a także w Didache, 15 (ustanowienie biskupów i diakonów). W obydwu wypadkach podkreśla się jednak mocno akt wybrania przez lokalny Kościół ${ }^{6}$. Drugim elementem liturgii

${ }^{4}$ Zob. B. Nadolski, Liturgika, dz. cyt., t. 3, s. 170.

${ }^{5}$ Zob. R. Hotz, Sakramente im Wechelspiel zwischen Ost und West, Zürich-Köln-Gütersloh 1979, s. 252.

${ }^{6}$ Zob. N. Afanasjew, Eklezjologija wstuplenija w klir, dz. cyt., s. 10-11. 


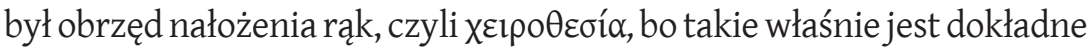
znaczenie tego greckiego słowa. Nałożeniu rąk towarzyszyła modlitwa

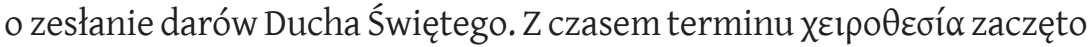
używać dla określenia całego sakramentu święceń. Z powyższych filologicznych rozważań wynika, że w pierwszych wiekach chrześcijaństwa

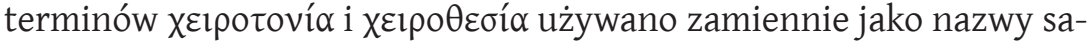
kramentu święceń wszystkich stopni.

Z czasem te dwa terminy posłużyły w Kościele bizantyjskim do rozróżnienia na wyższe i niższe stopnie kapłaństwa, co dokonało się nie bez wpływu zachodniej scholastyki. W XII wieku w Bizancjum określe-

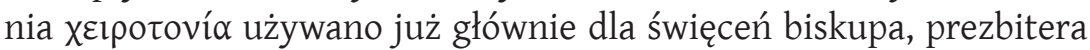

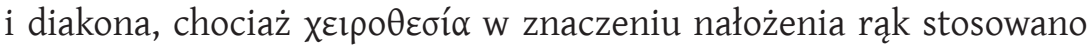
do wszystkich stopni święceń jeszcze w XV wieku7. Późniejsza szkolna

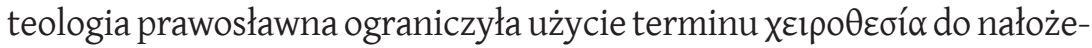
nia rąk przy ustanowieniach lektora i ipodiakona (subdiakona), tworząc różnice między nałożeniami rąk $k^{8}$. Odtąd więc xદıpotovía jako nałożenie

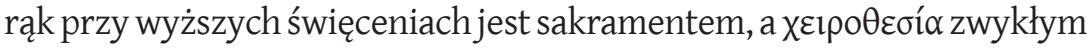
obrzędem, który nie komunikuje żadnych darów sakramentalnych. Tej zmiany znaczenia terminów dokonała nowa teologia dogmatyczna zmuszona niejako wykazać różnice jakości obrzędu nałożenia rąk wobec przyjętej klasyfikacji stopni święceń i określenia ich sakramentalności. Ta zmiana teologiczna nie wpłynęła jednak na samą liturgię wschodnią, która zachowała nałożenie rąk we wszystkich rodzajach święceń i według teologii liturgicznej tym właśnie gestem połączonym z modlitwą ustanawia się wszystkie posługi w Kościele`.

\section{Podział na niższe i wyższe święcenia}

we współczesnej liturgii bizantyjskiej

Poniżej przedstawimy aktualny podział różnych posług liturgicznych w Kościele prawosławnym. Do służenia w Kościele wezwani są wszyscy chrześcijanie. Istnieje jednak wiele różnych sposobów służenia. G. Nefedow, autor rosyjskiego podręcznika o sakramentach, dzieli członków

\footnotetext{
${ }^{7}$ Zob. tamże, s. 12-13.

${ }^{8}$ Zob. Veniamin, Nowaja skriżal (III.1, 3), Sankt Petersburg 1899, s. 262.

${ }^{9}$ Zob. N. Afanasjew, Eklezjologija wstuplenija w klir, dz. cyt., s. 14-15.
} 
Kościoła na „pasterzy” i „owce”, biorąc pod uwagę ich niejednakowy stopień udziału w czynnościach liturgicznych (pierwsi kierują liturgią, drudzy w niej uczestniczą, poddając się kierownictwu pierwszych) ${ }^{10}$. Jest to inaczej podział na duchowieństwo i świeckich. Zróżnicowane i hierarchicznie uporządkowane posługi liturgiczne wykonują przedstawiciele duchowieństwa rozumianego w prawosławiu szerzej niż u katolików. Do prawosławnego duchowieństwa (kleru) wchodzą dwie grupy ministrów - tzw. cerkownosłużyteli (ministrowie kościelni) i tzw. swjaszczennosłużyteli (ministrowie wyświęceni). Podział ten odpowiada dawnej zachodniej (przedsoborowej) klasyfikacji posług liturgicznych należących odpowiednio do grupy niższych i wyższych święceń z tą różnicą, że posiadających niższe święcenia nie uważano jeszcze za członków kleru.

Ustanowienie wyświęconych ministrów (diakon, prezbiter i biskup) dokonuje się przez obrzędy sakramentu kapłaństwa, który nazywa się w tradycji wschodniej rukopołożeniem. Nałożenie rąk ustanawiające

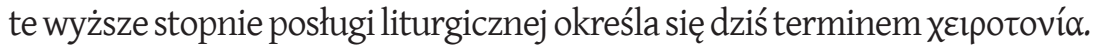
Pod wpływem Zachodu wyższe stopnie hierarchii mogą otrzymać tylko ci, którzy wcześniej przeszli przez wszystkie niższe stopnie.

Ustanowienie ministrów kościelnych (cztiec-lektor, piewiec-kantor, swieszczenosiec-akolita, ipodiakon-subdiakon) dokonuje się przez obrzędy kościelne (niesakramentalne), na które składa się nałożenie rąk i błogosławieństwo biskupa. Niesakramentalne nałożenie rąk nazywa się dziś

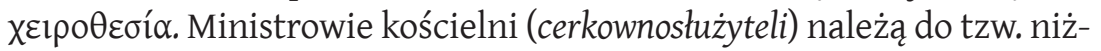
szego duchowieństwa. Według Nefedowa otrzymują oni łaski potrzebne do współudziału w obrzędach liturgicznych Kościoła, a we wszystkich swoich działaniach mają podporządkować się ministrom wyświęconym ${ }^{11}$.

Ważną obrzędową różnicą między ustanowieniem ministrów wyświęconych i ustanowieniem ministrów kościelnych jest miejsce, w którym odbywa się odpowiednia liturgia ustanowienia. W wypadku ustanowienia swjaszczennosłużytelej jest nim prezbiterium (ałtar), bo tam wypełniają oni swoje funkcje liturgiczne. Ministrowie kościelni ustanawiani są poza prezbiterium, gdyż ich funkcje liturgiczne nie są związane bezpośrednio

\footnotetext{
${ }^{10}$ Zob. G. Nefedow, Tainstwa i obrjady Prawosławnoj Cerkwi, Moskwa 1999, s. 199-200.

${ }^{11}$ Zob. tamże, s. 200.
} 
z ołtarzem (z wyjątkiem ipodiakona) ${ }^{12}$. Ponadto podczas gdy w czasie jednej liturgii można ustanowić kilku ministrów kościelnych naraz, sakramentalne rukopotożenie przeprowadzane jest tylko nad jednym kandydatem do wyższego stopnia kapłaństwa ${ }^{13}$.

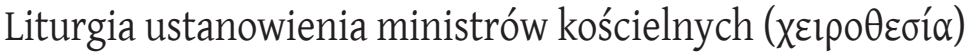

Jak już wspomniano wyżej, ustanawianie kandydatów na niższe stopnie służenia nie ma charakteru sakramentalnego, dlatego też nałożeniu rąk w tym wypadku nie towarzyszą słowa przyzywające łaskę kapłaństwa ${ }^{14}$. Wydaje się, że na pierwszy plan tych obrzędów wysuwa się błogosławieństwo udzielane przez biskupa. Poświęcenie do różnych stopni wyraża ubranie kandydatów w odpowiadające im szaty liturgiczne. Podkreślenie eklezjalnego wymiaru tych posług wyraża już samo nazwanie osób je wypełniających cerkownosłużyteliami (ministrowie kościelni).

Współczesna liturgiczna praktyka niższych święceń w Cerkwi rosyjskiej pozostaje taką, jaką znajdujemy w czynowniku archijerejskim z 1677 roku ${ }^{15}$. Już wówczas ustanowienie cztieca (lektora), piewca (kantora) i swieszczenosca (akolity) zlało się w jeden obrzęd. W związku z tym kandydat powoływany jest od razu do wykonywania tych trzech funkcji liturgicznych w zgromadzeniu: czytanie Apostoła ${ }^{16} \mathrm{i}$ śpiew troparionów ${ }^{17}$, noszenie świecy podczas małego i wielkiego wejścia. Porządek wspólnych obrzędów ustanowienia tych posług przedstawia się następująco:

${ }^{12}$ Ipodiakon ustanawiany poza prezbiterium wypełnia jednak swoje funkcje liturgiczne przy ołtarzu. Ta współczesna niekonsekwencja w obrzędach święceń wynika z dawnego podziału ministrów (w Bizancjum), według którego ipodiakon należał do ministrów wyświęconych - zob. N. Afanasjew, Eklezjologija wstuplenija w klir, dz. cyt., s. 15.

${ }^{13}$ Zob. M. Kunzler, Liturgia Kościoła, Poznań 1999, s. 482.

${ }^{14}$ Zob. G. Nefedow, Tainstwa i obrjady Prawosławnoj Cerkwi, dz. cyt., s. 204.

${ }^{15}$ Zob. A. Dmitriewskij, Stawlennik, Kiev 1904, s. 22-29.

${ }^{16}$ Apostoł - księga liturgiczna zawierająca lektury z Dziejów i Listów Apostolskich ułożone według porządku roku kościelnego; wyjaśnienia wschodniej terminologii liturgicznej na podstawie Słownika liturgicznego G. Minczewa zamieszczonego w: Beniamin, Nowe Tablice czyli o Cerkwi, liturgii... Wybór, Kraków 2007, s. 272-288.

${ }^{17}$ Troparion - krótki, jednostroficzny hymn liturgiczny składający się z kilku wersetów ku czci świętego lub święta liturgicznego. 
PIEWIEC

- błogosławieństwo biskupa,

- nałożenie rąk,

- modlitwa pierwsza,

- wykonanie troparionów przez poświęcanego,

- strzyżenie włosów (por. zachodnia tonsura)

- ubranie felonion $u^{18}$.

\section{CZTIEC}

- nałożenie rąk,

- modlitwa druga,

- czytanie Apostoła przez poświęcanego,

- zdjęcie felonionu.

\section{SWIESZCZENOSIEC}

- błogosławieństwo biskupa,

- pobłogosławienie sticharion $u^{19}$,

- ubranie sticharionu,

- pouczenie o obowiązkach cztieca,

- błogosławienie na cztieca,

- wręczenie świecznika ${ }^{20}$.

Wszystkie te obrzędy odbywają się przed rozpoczęciem Bożej liturgii (msza święta) na środku świątyni. Modlitwa po pierwszym nałożeniu rąk prosi Boga, by odział kandydata w czyste i niepokalane szaty i oświecił, aby mógł kiedyś otrzymać wieniec życia. Druga modlitwa to prośba o poświęcenie wybranego do służby lektora i obdarowanie go mądrością i rozumem, by mógł godnie czytać słowo Boże w świątyni. Wymownym obrzędowym momentem jest pierwsze wykonanie funkcji liturgicznych przez nowo ustanowionego - jako kantor śpiewa on tropariony, a jako lektor odczytuje fragment z Apostoła. W ten sposób minister kościelny

${ }^{18}$ Felonion - wierzchnia szata liturgiczna kapłanów.

${ }^{19}$ Sticharion - szata liturgiczna (odpowiednik zachodniej alby).

${ }^{20} \mathrm{~W}$ kolejności i tematach modlitw ustanowienia poszczególnych stopni można zauważyć pewne niekonsekwencje, zwłaszcza co do funkcji cztieca i swieszczenosca. Spowodowane są one faktem, że najpierw zlały się w jedno funkcje piewca i cztieca, a następnie ustanawianego do tych funkcji zaczęto nazywać swieszczenoscem. 
uroczyście inauguruje swoją liturgiczną służbę w Kościele. Pod koniec obrzędów ma miejsce pouczenie o najważniejszych obowiązkach ministra kościelnego w stopniu cztieca, a także wręczenie świecznika jako głównego atrybutu swieszczenosca ${ }^{21}$.

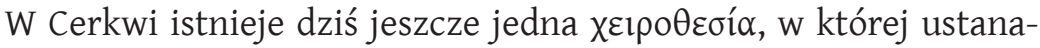
wia się ipodiakona (subdiakona). W swoim komentarzu Symeon Sołuński zaznacza odmienność tego stopnia od wyższych stopni kapłaństwa: ipodiakon poświęcony jest nie do udziału w modlitwach ołtarza, ale do służenia poza ołtarzem i do innych potrzeb Kościoła. Jeszcze przed błogosławieniem i nałożeniem rąk biskup przepasuje kandydata orarionem (wschodnia stuła diakońska), formując na jego plecach krzyż ${ }^{22}$. W modlitwie przy nałożeniu rąk wyprasza się dla ipodiakona pomoc Bożą, aby mógł godnie służyć Kościołowi świętemu, kochając i dbając o dom Boży. Znakiem inauguracji jego funkcji jest udział w obrzędzie umycia rąk biskupa. Po rozpoczęciu liturgii (mszy) ipodiakon podejmuje przeznaczone mu funkcje liturgiczne, pomagając diakonowi ${ }^{23}$.

\section{Liturgia ustanowienia ministrów wyświęconych

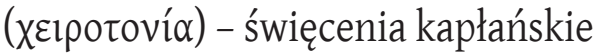

Ministrowie wyświęceni, czyli swjaszczennosłużyteli, do których należą diakon, prezbiter i biskup, posiadają wyższe i sakramentalne stopnie kapłaństwa. Dla potrzeb i pod kątem naszego tematu, to jest pokazania eklezjologicznego aspektu sakramentu kapłaństwa, omówimy teraz przebieg i znaczenie obrzędów ustanowienia prezbitera. Różnią się one w niewielkim stopniu od obrzędów święceń diakonatu, dlatego w naszym opracowaniu zdecydowaliśmy skoncentrować się na święceniach prezbiteratu.

W dosłownym przekładzie na język rosyjski słowo „prezbiter” brzmi stariec. Pojęcie to, występujące we wschodniej tradycji duchowości, niesie ze sobą ładunek duchowej powagi, autorytetu, doświadczenia, wskazuje

${ }^{21}$ Zob. G. Nefedow, Tainstwa i obrjady Prawosławnoj Cerkwi, dz. cyt., s. 206-207.

${ }^{22} \mathrm{~W}$ taki sam sposób nosi też orarion diakon. Skrzyżowany na plecach orarion symbolizuje skrzydła anielskie, gdyż posługa diakońska porównywana jest do służby aniołów będących pośrednikami między tronem Bożym a ludźmi.

${ }^{23}$ Zob. G. Nefedow, Tainstwa i obrjady Prawosławnoj Cerkwi, dz. cyt., s. 208-209. 
na fakt, że na prezbiterów pierwotny Kościół wybierał ludzi najbardziej doświadczonych i mądrych. W Kościele wschodnim prezbiter nazywany jest też często „ojcem” (otiec, batiuszka), gdyż przez sprawowanie sakramentów i głoszenie słowa Bożego przyczynia się do duchowego odrodzenia wierzących. Symeon Sołuński charakteryzuje ten stopień kapłaństwa jako „wykonujący, odprawiający” (sowierszytelnyj), ponieważ prezbiter, sprawując sakramenty, nie może przekazać samego daru kapłaństwa innym osobom: „Prezbitera nazywa się odprawiającym, jako że ma tylko łaskę sprawowania obrzędów, nie zaś przekazywania [łaski]. Chrzci bowiem

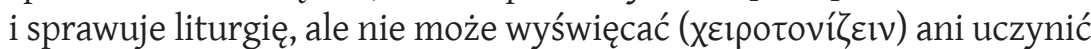
kogo innego kapłanem ani [innym] członkiem stanu duchownego"24.

Prezbiterowi podporządkowani są diakon i wszyscy ministrowie niższych stopni, którzy wypełniają swoje funkcje liturgiczne w świątyni tylko z jego błogosławieństwem. Sakrament kapłaństwa udzielany jest podczas Bożej liturgii na samym początku liturgii eucharystycznej. Schemat najważniejszych obrzędów święceń kapłańskich przedstawia się następująco:

- wezwanie: Poweli, powelite, poweli, preoswjaszczennyj władyko,

- trzykrotne okrążenie ołtarza przy śpiewie troparionów,

- klęczenie przed ołtarzem na oba kolana,

- nałożenie omoforionu ${ }^{25}$ na głowę wyświęcanego,

- błogosławieństwo biskupa,

- włożenie ręki biskupa na głowę wyświęcanego,

- sakramentalna modlitwa Boża łaska...,

- modlitwa pierwsza,

- modlitwa druga,

- mirnaja ektenia ${ }^{26}$

- ubieranie szat liturgicznych (epitrachilion ${ }^{27}$, pas, felonion), wręczenie krzyża i służebnika z wezwaniami Dostoin ("A $\xi 10 \varsigma)$;

- pocałunek pokoju z koncelebrantami,

${ }^{24}$ Symeon z Tessaloniki, o świątyni Bożej, tłum. A. Maciejewska, Kraków 2007, s. 49.

${ }^{25}$ Omoforion - szeroki jedwabny pas ozdobiony krzyżami, noszony na ramionach, element szaty liturgicznej biskupa i oznaka jego godności.

${ }^{26}$ Ektenia - modlitwa diakona (lub kapłana) o pokój składająca się z wielu próśb, na które chór (wierni) odpowiada Kyrie eleison (Gospodi pomiłuj).

${ }^{27}$ Epitrachilion - długi pas ozdobiony siedmioma krzyżykami, oznaka urzędu kapłańskiego (odpowiednik zachodniej stuły). 
- przekazanie nowo wyświęconemu kapłanowi cząstki Agnca po przeistoczeniu darów,

- Psalm 50,

- komunia święta,

- czytanie modlitwy zaambonnej (końcowej) ${ }^{28}$.

Obrzędy rozpoczynają się od uroczystego przyprowadzenia kandydata (diakona) do carskiej bramy ikonostasu przez diakonów. Równi mu w stopniu zostawiają go w drzwiach, ponieważ będzie on poświęcony na wyższy stopień kapłaństwa, zostaje tam przejęty przez dwóch prezbiterów i wprowadzony do prezbiterium ${ }^{29}$.

Obrzędy wstępne - wybór kandydata na prezbitera

Wprowadzeniu kandydata towarzyszy starożytne wezwanie: Poweli, powelite, poweli, preoswjaszczennyj władyko („Dozwól, dozwólcie, dozwól, czcigodny władco"). W kontekście współczesnego przebiegu obrzędów święceń wezwanie to nie ma jakiegoś specjalnego znaczenia. Według Nikołaja Afanasjewa jest to jednak wyraźne świadectwo liturgii o obrzędowym wyborze kandydata ze strony Kościoła mającym kiedyś miejsce na początku święceń ${ }^{30}$. Prawodpodobnie to wezwanie zaczerpnięte z imperatorskiego ceremoniału bizantyjskiego zamieniło kiedyś bar-

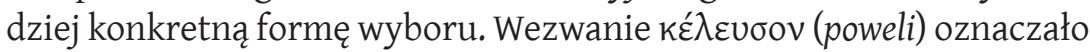
pytanie imperatora o zgodę na przeprowadzenie jakiegoś działania. Pierwsze wezwanie odnosi się do samego kandydata (poweli), ostatnie (trzecie) - do prowadzącego obrzędy biskupa (poweli preoswjaszczennyj władyko). Drugie wezwanie w liczbie mnogiej (powelite) było symbolicznym zwróceniem się do zebranych w celu uzyskania ich zgody na wyświęcenie kandydata ${ }^{31}$.

W Kościele starożytnym ustanowienie prezbitera jak każde inne działanie kościelne wymagało wcześniejszej zgody całej miejscowej

${ }^{28}$ Zob. G. Nefedow, Tainstwa i obrjady Prawosławnoj Cerkwi, dz. cyt., s. 213.

${ }^{29}$ Zob. Veniamin, Nowaja skrizal, dz. cyt., s. 263.

${ }^{30}$ Zob. N. Afanasjew, Eklezjologija wstuplenija w klir, dz. cyt., s. 37.

${ }^{31}$ Zob. N. Aksakow, Predanie Cerkwi i predanie szkoły, Sergiew Posad 1910, s. 128. A. Niesielowski uważa, że drugie wezwanie zwraca się nie do wszystkich wiernych, ale tylko do zebranego duchowieństwa - zob. A. Niesielowskij, Cziny chirotesij i chirotonij, Kamieniec Podolskij 1906, s. 157-158. 
wspólnoty. Rola biskupa-konsekratora sprowadzała się do tego, żeby na początku liturgii upewnić się o zgodzie wspólnoty na wyświęcenie danego kandydata. W Tradycji Apostolskiej Hipolita Rzymskiego czytamy, że diakona wybiera się „,tak jak powiedziano wyżej”, czyli tak jak biskupów wybieranych przez cały lud ${ }^{32}$. Ten porządek jednak dość szybko uległ zmianie. W północnej Afryce za czasów św. Cypriana wybór prezbiterów i diakonów dokonywał się już w gronie należących do prezbiterium. Ostatecznie wierni stracili możliwość wybierania swoich pasterzy na przełomie IV i V wieku. Upadła także rola prezbiterium, które odtąd pełniło jedynie rolę doradczą przy biskupie. Wskutek tego wybór i ustanowienie prezbiterów, a tym bardziej pozostałych członków kleru, stał się kompetencją biskupa. W XII wieku w Bizancjum zapomniano już całkowicie, że kiedyś prezbiterów Kościoła wybierali wierni ${ }^{33}$.

Z tego krótkiego ekskursu historycznego wynika, że pierwszy i bardzo ważny moment sakramentu kapłaństwa - wybór ze strony Kościoła - uległ znaczącym przeobrażeniom. W większości współczesnych autokefalicznych Cerkwi prawosławnych prezbiterzy i inni członkowie duchowieństwa są mianowani przez biskupa ${ }^{34}$. Mianowanie, które zastąpiło wybór, zostało oddzielone też od liturgii święceń i nie uważa się go za część składową sakramentu kapłaństwa. Współczesna teologia prawosławna, mówiąc o udzielaniu sakramentu kapłaństwa, wskazuje tylko na same obrzędy sensu stricto. Wybór kandydatów traktowany jest przez niąjako moment prawny. Tymczasem Nikołaj Afanasjew zwraca uwagę, że ten wybór w pierwotnym Kościele nie miał charakteru prawnego. Wybór miał na celu objawienie woli Bożej w Kościele. Był więc służbą całej wspólnoty wiernych, a nie jej prawem ${ }^{35}$. Akt wyboru był także integralną częścią liturgii sakramentu kapłaństwa, ważną nie mniej

${ }^{32}$ Zob. Ippolito di Roma, La Tradizione Apostolica, introduzione, traduzione e note a cura di R. Tateo, Milano 1995, s. 58 (II, 1) i s. 67 (VIII, 1).

${ }^{33}$ Zob. N. Afanasjew, Eklezjologija wstuplenija w klir, dz. cyt., s. 34-35.

${ }^{34}$ Ojciec Ludwik Gillet (Mnich Kościoła Wschodniego) dostrzega tu widzialny element kapłaństwa (wybór, delegacja, mandat - synonimy). Przez delegację rozumie akt, poprzez który miejscowa wspólnota chrześcijańska lub działający w jej imieniu biskup wyznacza danego człowieka do pełnienia służby kapłańskiej. Zawsze powinien zostać wybrany najlepszy kandydat - zob. Mnich Kościoła Wschodniego, Ofiara liturgiczna, Bydgoszcz-Kijów-Kraków 1999, s. 73.

${ }^{35}$ Zob. N. Afanasjew, Eklezjologija wstuplenija w klir, dz. cyt., s. 36. 
niż następujące po nim dalsze obrzędy. Jak widzieliśmy wyżej, wschodnia liturgia święceń zachowała jednak w wezwaniach Poweli, powelite... wyraźne świadectwo tej dawnej praktyki.

Po tych wezwaniach zaskakuje nas obrzęd wzięty niemalże w całości z liturgii sakramentu małżeństwa (wienczanie) - charakterystyczne dla niej trzykrotne okrążenie ołtarza ze śpiewem troparionów ${ }^{36}$. Procesja ta obecna w zarówno w obrzędach sakramentu kapłaństwa, jak i małżeństwa otrzymuje trafną, eklezjologiczną interpretację G. Niefedowa: „W prezbiterium, przy ołtarzu dokonuje się ślub kandydata z Kościołem i poświęcenie do szczególnej służby Kościołowi, dlatego podczas trzykrotnego obchodzenia ołtarza, śpiewa się te same tropariony, co przy celebrowaniu sakramentu małżeństwa" ${ }^{37}$.

W pierwszym troparionie Święci męczennicy wzywa się męczenników, którzy przyczynili się do umocnienia i wzrostu Kościoła. Drugi troparion Chwała Tobie, Chryste Boże przypomnieć ma wyświęcanemu, że swoim głoszeniem słowa Bożego ma przynosić chwałę Trójcy Świętej. W trzecim troparionie Izajaszu, raduj się wychwalany jest jeden z największych dogmatów chrześcijańskich - wcielenie Syna Bożego z Maryi Dziewicy. Przyszły kapłan ma w sercu i umyśle nosić ten dogmat i całym życiem swoim świadczyć o czci Zbawiciela i Bogurodzicy.

\section{Obrzędy sakramentalne liturgii święceń}

Następnie kandydat do prezbiteratu klęka na obydwa kolana przy ołtarzu (w święceniach diakonatu - na jedno kolano), a biskup nakłada ręce na głowę kandydata i wygłasza modlitwę-aklamację Łaska Boża... ('H Өzía Xópıৎ - Bożestwennaja błagodat): „Łaska Boża, która zawsze leczy to, co słabe, i uzupełnia to, czego brakuje, wybiera tego jako prezbitera (diakona, biskupa). Módlmy się przeto za niego, aby zstąpiła nań łaska Ducha Świętego" 38 .

${ }^{36}$ Uwieńczeni koronami młodzi (stąd wienczanie) okrążają tetrapod (wysoki stolik z ikoną), kandydat do święceń natomiast chodzi wokół ołtarza.

${ }^{37}$ G. Nefedow, Tainstwa i obrjady Prawosławnoj Cerkwi, dz. cyt., s. 211.

${ }^{38}$ B. Botte, La formule d'ordination „La grace divine” dans les rites orientaux, „L'Orient Syrien" 2 (1957), s. 289. 
Niektórzy badacze liturgii uważają tę ważną i obecną w wielu obrządkach wschodnich modlitwę za formułę konsekracyjnąą, ale na ten temat zdania są podzielone ${ }^{40}$. Jako modlitwę sakramentalną przyjmuje ją wschodnia tradycja słowiańska, zarówno greckokatolicka, jak i prawosławna, ulegając w tym względzie wpływom łacińskim (ścisłe ustalenie formy sakramentu). Nas interesuje jednak ta modlitwa ze względu na ciekawą funkcję proklamacji wyboru, w tym wypadku ze strony samego Boga ${ }^{41}$. Wybór Boży potwierdza tutaj wybór dokonany przez wspólnotę Kościoła. Zwraca na to uwagę w swojej analizie tekstu Nikołaj Afanasjew. W tekście cerkiewnym czasownik proruczestwowat

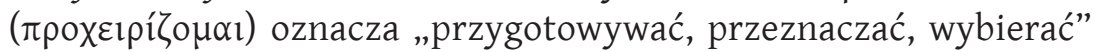
(zob. np. Dz 22,14). Ta formuła liturgiczna wypowiadana przez biskupa wyraża prawdę, że kandydat do kapłaństwa jest wybrany przez samego Boga. Przypuszczalnie formuła ta została wprowadzona do obrzędów wtedy, gdy święcenia odbywały się nie w tym kościele, w którym miał wypełniać swoją służbę przyszły prezbiter. Są podstawy, aby uważać, że modlitwa 'H Acía xópı zamykała część obrzędu związaną z wyborem kandydata. Według Afanasjewa także to liturgiczne wezwanie biskupa świadczy o dawnej praktyce Kościoła, gdy wybór przez wspólnotę tego, kto był powołany (przeznaczony) przez Boga do świętej służby, stanowił istotny moment obrzędów sakramentu kapłaństwa ${ }^{42}$. Współcześnie kandydat nie jest wybierany, ale wyznaczany - mianowany przez biskupa. $\mathrm{Z}$ tego powodu jednak nie zmienia się zasadniczo sens samej modlitwy

${ }^{39}$ Tak uważa np. B. Botte - zob. tamże, s. 301.

${ }^{40} \mathrm{~W}$ niektórych Kościołach wschodnich modlitwę tę wypowiada archidiakon - jest ona rodzajem zapowiedzi święceń i potwierdzeniem właściwie przeprowadzonego wyboru kandydata (F. Heiler, Urkirche und Ostkirche, München 1937, s. 276). Widzenie w niej formuły ustanawiającej kapłana P. Trembelas uważa za niedopuszczalną latynizację sakramentu święceń, ponieważ epikleza konsekracyjna rozsiana jest po całym obrzędzie i znajduje się przede wszystkim w modlitwach (P. N. Trembelas, Dogmatique de l'Eglise orthodoxe catholique, Chevtogne-Bruges 1968, s. 327n). M. Kunzler sądzi, że byłoby lepiej traktować tę modlitwę jako jedną całość razem z dwiema cichymi modlitwami biskupa następującymi zaraz po niej (M. Kunzler, Liturgia Kościoła, dz. cyt., s. 483).

${ }^{41}$ Pseudo-Dionizy nazywa tę modlitwę proklamacją (anarresis) i epiklezą. Możliwe, że odpowiada ona zachodniej formule Auxiliante Domino... (,Z pomocą Bożą wybieramy..." - Ordo Romanus XXXVI, nr 16) - zob. P. De Clerck, Ordination, orde, [w:] Catholicisme, t. 10, Paris 1984, s. 202.

${ }^{42}$ Zob. N. Afanasjew, Eklezjologija wstuplenija w klir, dz. cyt., s. 37-38. 


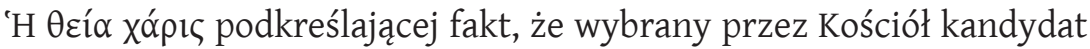
do kapłaństwa jest ostatecznie wybrańcem Bożym.

Modlitwa ta należy dziś wyraźnie do obrzędów święceń, a według niektórych tradycji liturgicznych stanowi nawet ich kulminację (patrz wyżej).Przyjmując jej eklezjologicznąinterpretację (autorstwa Afanasjewa), możemy zaryzykować twierdzenie, że przez nią treści sakramentu kapłaństwa związane z wyborem ze strony Kościoła i ze strony Boga pozostały obecne w samej ściśle liturgicznej części obrzędu. W tekście omawianej aklamacji znajduje się także wyraźne wezwanie całej wspólnoty Kościoła obecnej na święceniach do modlitwy za kandydata („módlmy się przeto za niego, by zstąpiła nań łaska Ducha Świętego”).

Następują dwie ciche modlitwy biskupa odmawiane podczas trwającego nadal nałożenia rąk. W pierwszej biskup prosi Boga, aby pomógł wybranemu przezeń prezbiterowi podjąć wielką łaskę Ducha Świętego daną dla nieskalanego życia i nieugiętej wiary. Druga modlitwa stanowi jakby podsumowanie i zakończenie procesu ustanowienia prezbitera. Ukazuje ona najważniejsze zadanie wyświęcanego kapłana, jakim jest przedłużanie w Kościele misterium zbawienia ludzi, którego dokonuje łaska Chrystusa za pośrednictwem pasterza dusz. To główne zadanie realizuje się poprzez wyliczone w modlitwie następujące działania kapłana:

1) stanie przy ołtarzu ofiarnym i składanie w ofierze swojego życia,

2) głoszenie Ewangelii Królestwa i umacnianie wiary w Chrystusa Zbawiciela świata,

3) głoszenie Bożej i Chrystusowej prawdy własnym przykładem,

4) sprawowanie liturgii Bożej,

5) ukazywanie światu Bożego ojcostwa przez udzielanie chrztu i dbanie o duchowy wzrost ochrzczonych ${ }^{43}$.

Według J. M. Hanssensa to właśnie te dwie ciche modlitwy biskupa, które nazywa on epikletycznymi, składają się na formę wschodniego sakramentu święceñ ${ }^{44}$. Podczas pierwszej wierni i duchowieństwo śpie-

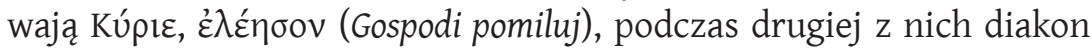
intonuje ektenię o pokój: „Módlmy się za sługę Bożego... wyświęcanego (teraz) na kapłana, o jego zdrowie i zbawienie".

${ }^{43}$ Zob. G. Nefedow, Tainstwa i obrjady Prawosławnoj Cerkwi, dz. cyt., s. 214.

${ }^{44}$ Zob. J. M. Hanssens, La forme sacrementelle dans les ordinations sacerdotales de rite grec, „Gregorianum” 6 (1925), s. 75-80. 
Jeśli pewne spory toczą się wokół znaczenia wyżej wspomnianych trzech modlitw dla całości święceń, to współczesna prawosławna teologia dogmatyczna i liturgiczna, a także wschodnie prawo kanoniczne nie mają wątpliwości w kwestii gestów i wskazują nałożenie rąk biskupa

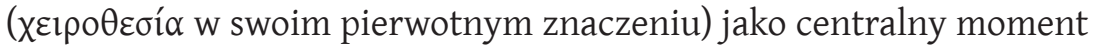
sakramentu kapłaństwa. Tak pisze o nim Ludwik Gillet (Mnich Kościoła Wschodniego), nawiązując do podkreślanego przez nas udziału wspólnoty w sakramencie święceń: „Kapłaństwo nie jest skutkiem samej tylko decyzji powszechnego głosowania wspólnoty chrześcijańskiej. Trzeba jeszcze, by poprzez akt święceń nowy kapłan został publicznie, oficjalnie włączony w długi łańcuch kapłanów, na których biskupi włożyli swe ręce. Biskup, zobowiązany do przekazywania świadectwa i wiary Apostołów, dołącza nowego kapłana do tradycji apostolskiej”"45.

Biskup nakładający ręce na wybranych jest jednak także reprezentantem wspólnoty Kościoła, bo on jej przewodzi i nad nią czuwa. W Kościele starożytnym nie stawiano zresztą pytania, kto udziela sakramentu, gdyż w eklezjalnej świadomości wszystkie sakramenty sprawuje Kościół, gdy lokalna wspólnota kościelna zebrana jest na czele ze swoim biskupem. To biskup w otoczeniu swoich prezbiterów przewodniczył Eucharystii, udzielał chrztu i bierzmowania. Przewodniczenie liturgii sakramentu kapłaństwa pozostało do dziś przywilejem biskupów jedynie $\mathrm{z}$ tą różnicą, że obowiązujące kanony Cerkwi prawosławnej pozwalają nakładać ręce i ustanawiać prezbiterów tylko aktywnym biskupom, to jest tym, którzy przewodzą konkretnemu Kościołowi lokalnemu (biskupom diecezjalnym). Święcenia kapłańskie sprawuje więc biskup jako przełożony swojego Kościoła. Nakładając ręce, biskup działa nie indywidualnie, ale w imieniu Kościoła. Celebruje obrzędy sakramentu kapłaństwa na liturgicznym zebraniu lokalnego Kościoła ${ }^{46}$. Nikołaj Afa-

${ }^{45}$ Mnich Kościoła Wschodniego, Ofiara liturgiczna, dz. cyt., s. 73-74. Cytowany autor podkreśla dalej, że sukcesja apostolska wyrażona w nałożeniu rąk nie oznacza tylko zewnętrznej ciągłości, ale ma wymiar wewnętrzny, duchowy i wskazuje na łaskę tego samego Ducha Świętego, którego wszyscy otrzymali od Jezusa.

${ }^{46} \mathrm{~W}$ okresie przednicejskim (przed 325 rokiem) wszyscy prezbiterzy byli wyświęcani przez biskupa w jego własnym kościele, ponieważ mieli wykonywać swoją służbę w tymże kościele biskupim. Gdy zaczęły tworzyć się nowe miejskie i wiejskie parafie na czele z prezbiterami, poprzedni porządek udzielania święceń został zachowany - biskup wyświęcał prezbiterów w kościele katedralnym. Wytworzyła się sytuacja, że dana lo- 
nasjew podkreśla, że taki właśnie był aksjomat starożytnego Kościoła wypływający z nauczania o sakramentach. Sakramenty sprawowane są przez Kościół i w Kościele, poza Kościołem nie może być żadnych sakramentów ${ }^{47}$. Do tej tradycji nawiązuje współczesna praktyka Kościoła prawosławnego, która nie zezwala wyświęcać więcej niż jednego prezbitera za jednym razem i w której szafarzem sakramentu święceń ma być biskup miejsca.

Obrzędy wyjaśniające - przyjęcie wyświęconego prezbitera

Nałożenie rąk, jak wykazaliśmy wyżej, było i pozostaje we wschodniej liturgicznej tradycji istotnym obrzędem sakramentalnym, świętym działaniem, w którym i przez które Kościół pod przewodnictwem biskupa wyprasza potrzebne dary łaski dla wyznaczonego do służby kapłańskiej. W zwyczajach Kościoła starożytnego po tym geście miało miejsce uroczyste przyjęcie, recepcja sakramentu święceń i samego neoprezbitera, który je otrzymał. Było nim świadectwo ze strony całego ludu, że sakrament został ważnie udzielony, dary łaski zesłane przez Boga i nowy kapłan może rozpocząć swoją służbę we wspólnocie ${ }^{48}$. Jakie były formy obrzędowe tego świadectwa i przyjęcia święceń ze strony Kościoła? Po nałożeniu rąk nowo wyświęcony biskup, prezbiter lub diakon zajmowali miejsca w zgromadzeniu liturgicznym przysługujące im od momentu święceń. Zajęcie tych miejsc odbywało się za zgodą Kościoła, który w ten sposób przyjmował zrealizowany w nowych pasterzach sakrament kapłaństwa. Zewnętrznym znakiem tej zgody był pocałunek pokoju. Potwierdzenie tej praktyki znajdujemy w Tradycji Apostolskiej Hipolita Rzymskiego opisującego święcenia biskupie. Po konsekracji duchowieństwo i lud, którzy śledzili tę ceremonię w ciszy, wyrażają swoją zgodę na wybór, dając nowemu biskupowi pocałunek pokoju

kalna wspólnota kościelna, którą stała się parafia, nie wiedziała, kto będzie ustanowionym dla niej prezbiterem. Według Afanasjewa przy obecnej organizacji kościelnej święcenia powinny odbywać się w tej parafii, w której wyświęcany podejmie swoją służbę. Sądząc z punktu widzenia Kościoła starożytnego (okresu przednicejskiego), wszystkie święcenia mające miejsce poza parafią należałoby uważać za tajne - zob. N. Afanasjew, Eklezjologija wstuplenija w klir, dz. cyt., s. 44.

\footnotetext{
${ }^{47}$ Zob. N. Afanasjew, Eklezjologija wstuplenija w klir, dz. cyt., s. 40-42.

${ }^{48}$ Zob. tamże, s. 47-48.
} 
i nazywając go ớ lo $^{49}$ : „Po tym jak wybrany zostanie ustanowiony biskupem, wszyscy go pozdrowią i dadzą mu pocałunek pokoju, ponieważ tego stał się godzien (pozdrowią go, mówiąc: stał się godny - ớł10ৎ)"

Pocałunek pokoju w obrzędach święceń kapłańskich tak jak pocałunek przy przyjmowaniu nowego członka Kościoła stanowi świadectwo ludu o przekazaniu nowo wyświęconemu darów Ducha Świętego, gdyż godnym służby w Kościele jest ten, kto otrzymał dary ducha. Te dane potwierdza inny dokument starożytności kościelnej Konstytucje Apostolskie. Znajdujemy w nim nie tylko zwyczaj pocałunku pokoju o powyższym znaczeniu, ale także aklamację „Amen”, którą wypowiadają na koniec modlitwy ustanowienia inni obecni na liturgii kapłani, a z nimi cały lud ${ }^{51}$.

W dzisiejszej praktyce Kościoła prawosławnego nie ma już tak wyraźnego aktu przyjęcia przez wspólnotę ustanowionego dla niej prezbitera. Afanasjew jako przyczynę utraty tego obrzędu podaje wspomniany już fakt, że święcenia odbywają się dziś zazwyczaj nie w tym kościele (parafii), dla którego prezbiter zostaje wyświęcony. Niemniej jednak współczesne liturgiczne obrzędy święceń zachowały ślady dawnego świadectwa ludu. Wprawdzie znikł z nich pocałunek pokoju ze wszystkimi uczestnikami zgromadzenia, ale neoprezbiter wymienia go ze współcelebransami. Funkcję akceptacji nowo wyświęconego ze strony całego ludu częściowo przejął natomiast obrzęd ubierania szat liturgicznych. Przy ubieraniu poszczególnych szat i wręczaniu ordynandowi paramentów liturgicznych kilkakrotnie śpiewane jest uroczyście wezwanie Dostoin (Aksios). Aksios intonuje najpierw biskup konsekrator, za nim wezwanie to podejmują koncelebrujący prezbiterzy i wreszcie całe zgromadzenie reprezentowane zwykle przez cerkiewny chór ${ }^{52}$. Takie wyrażenie recepcji święceń przez zgromadzony na liturgii Kościół ma dzisiaj znaczenie czysto symboliczne, gdyż faktycznie o godności neoprezbitera nie może zaświadczyć wspólnota, która nie miała praktycznego udziału w jego wyborze ani nie będzie bezpośrednio korzystać

${ }^{49}$ Zob. R. Tateo, Introduzione, [w:] Ippolito di Roma, La Tradizione Apostolica, dz. cyt., s. 30.

${ }^{50}$ Ippolito di Roma, La Tradizione Apostolica, dz. cyt., s. 61 (IV, 1) i przyp. 16.

${ }^{51}$ Zob. Konstytucje Apostolskie, VIII, 5, [za:] N. Afanasjew, Eklezjologija wstuplenija w klir, dz. cyt., s. 48.

${ }^{52}$ Zob. G. Nefedow, Tainstwa i obrjady Prawosławnoj Cerkwi, dz. cyt., s. 211 i 213. 
z jego duszpasterskiej posługi ${ }^{53}$. Mimo to niektórzy autorzy widzą tutaj przejaw aktywnego udziału wszystkich uczestników liturgii święceń na mocy ich królewskiego kapłaństwa ${ }^{54}$.

\section{Podsumowanie - rola Kościoła w liturgii sakramentu kapłaństwa}

Obrzędy liturgii sakramentu święceń w obrządku wschodnim są mocną podstawą dla rozwijania eklezjologii kapłaństwa i same niejako ją zawierają w myśl zasady lex orandi lex credendi. Mogliśmy się o tym przekonać, śledząc wyżej ich przebieg i treść, zwracając szczególną uwagę na rolę i zadanie obecnej na liturgii wspólnoty Kościoła w udzielaniu sakramentu. $Z$ tego punktu widzenia liturgie sakramentu święceń kapłańskich podzieliliśmy na trzy części:

1) wybór przez Kościół kandydata przeznaczonego do służby kapłańskiej,

2) obrzędy sakramentalne - nałożenie rąk z wyproszeniem darów Ducha Świętego,

3) recepcja święceń i wyświęconego ze strony Kościoła.

Centralnym momentem święceń jest bez wątpienia sakramentalne działanie wyrażające się w sięgającym czasów apostolskich geście nałożenia rąk. Wtedy sam Bóg zsyła na wybranego dary Ducha Świętego, bez których niemożliwa jest służba w Kościele. Sakramentalne nałożenie rąk nie może być jednak rozpatrywane w izolacji od pozostałych obrzędów i jego pełnego znaczenia nie da się zrozumieć bez pierwszej i trzeciej części liturgii, które wyrażają istotną rolę wspólnoty Kościoła w całej celebracji święceń. Służba w Kościele niemożliwa jest bez uświęcającego działania Ducha, ale nie może zostać zainaugurowana bez udziału samego Kościoła. Obrzędy pierwszej i trzeciej części liturgii mimo historycznych zmian, jakie się w nich dokonały, nie przestają świadczyć o aktywnym działaniu wspólnoty kościelnej w procesie ustanowienia jej nowych pasterzy. Obrzędy wstępne (1) przypominają, że wybór kandydata przez wspólnotę był kiedyś integralną częścią liturgii sakramentu. Nie bez przyczyny także terminem xeıpotovía, pierwotnie

\footnotetext{
${ }^{53}$ Zob. N. Afanasjew, Eklezjologija wstuplenija w klir, dz. cyt., s. 49.

${ }^{54}$ Zob. F. Heiler, Urkirche und Ostkirche, München 1937, s. 277.
} 
odnoszącym się do wyboru przez głosowanie, nazywa się dziś cały sakrament święceń. Czy pozostawienie tej nazwy tylko przy wyższych stopniach święceń (diakon, prezbiter, biskup) nie sugeruje, że w związku z ich znaczeniem dla Kościoła powinny one dokonywać się nadal z uwzględnieniem opinii całej wspólnoty? W części zamykającej liturgię święceń (3) wspólnota Kościoła potwierdza ich ważność - z radością przyjmuje tego, który został obdarowany łaską przez samego Boga i potwierdza jego godność ("A łı za sensu stricto sakramentalne (2), stwarzające przestrzeń dla Bożego działania zawierają również elementy związane z działaniem Kościoła. W aklamacji Bozhestwennaja blagodat wybór Boży potwierdza wybór Kościoła, ciche modlitwy opisują zadania kapłana w Kościele, a biskup nakładający ręce występuje w imieniu miejscowej wspólnoty kościelnej. Wschodnia tradycja liturgiczna pokazuje również, że posługiwanie biskupa, prezbitera i diakona nie jest wyizolowane, ale wsparte przez

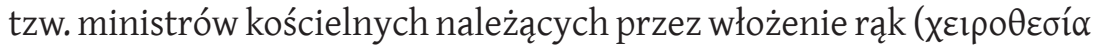
- niższe święcenia) do szeroko pojętego kleru, którzy wypełniają prawdziwe funkcje liturgiczne, dzieląc odpowiedzialność za życie Kościoła.

Świadectwo liturgii wschodniej, która w obrzędach święceń różnych stopni przechowała oryginalną eklezjologię pierwszych wieków, może być dzisiaj ze wszech miar pożyteczne i pomocne nie tylko w rozwoju nowych perspektyw teologicznych, ale w stopniowym odzyskaniu przez wspólnotę Kościoła aktywnej roli w wyborze i ustanowieniu swoich ministrów i pasterzy.

Kraków

PRZEMYSEAW NOWAKOWSKI CM

\section{Słowa kluczowe}

Kościół, liturgia, sakrament, kapłaństwo, obrzędy, nałożenie rąk, ustanowienie, służba, prezbiter, wybór 


\section{Summary}

\section{Liturgical Ecclesiology of the Sacrament of Ordination in the Eastern Rite}

The subject matter of the above paper is the role and position of the Church community in the rite of ordination to the priesthood in the byzantine tradition. It has been considered the split of the orthodox ministers into the church ministers (lower ordination) and ordained ministers (higher ordination). The influence of the local community upon the election of the candidates to priesthood has been weakened with time and nowadays within the Orthodox Church only the local bishop decides about the appointment of the new ministers and only the imposition of hands is regarded as the sacramental rite. The contemporary liturgy of ordination, however, has preserved some significant elements reminding us about the former equal importance of the community influence, who used to elect by offering to God and at the same time to accept their shepherds. This role of the Church is expressed by three main parts of the rites: 1) the election of a candidate, 2) the imposition of hands of the bishop and prayer, 3) the reception of ordination and of the newly ordained. Out of the presented liturgy of ordination one can draw the outline of the eastern ecclesiology of the sacrament of ordination, already elaborated by Prof. N. Afanasiev. This kind of liturgical ecclesiology may be of some help to the contemporary Church in regaining her more active role in electing and apointing her ministers and shepherds.

\section{Keywords}

Church, liturgy, Holy Orders, rite, imposition of hands, apointment, minister, service, priest, election 
